\title{
A Changing Industry: Academic Business Education in Israel
}

\author{
Tamar Almor, College of Management, Israel \\ Diana Bank, Universidad de las Américas Puebla (UDLAP), Mexico
}

By EARLY 2013, ISRAEL'S POPULATION was close to the eight million mark. The country, which is based on a market economy, with an estimated Gross Domestic Product (GDP) per capita (PPP) of about $\$ 32,000$, is considered the only democratic country in the Middle East. During the last decades, Israel has emerged as an important global center of innovation and entrepreneurship. Knowledge-intensive industries, as well as private and public venture capital (both Israeli and international), have allowed for industry and service sectors to flourish, including that of tertiary education.

Even though Israel as a nation has only existed since 1948, various tertiary education institutions were already established as early as the 1920s in the land that constituted the British Mandate of Palestine. In 1924, the Technion Israel Institute of Technology was established in the Northern city of Haifa and the Hebrew University in Jerusalem followed in 1925. Soon thereafter, others were founded: The Weizmann Institute of Science in 1934; Bar Ilan University in 1955; Tel Aviv University in 1956; the University of Haifa in 1963; Ben Gurion University of the Negev in 1969; and The Open University in 1976. In 1990-91, these eight universities provided higher education for about 81,000 students $^{2}$ and remain the most important educational institutes in Israel, with a very good international reputation. According to QS World University Rankings (2012), four of these eight universities were ranked among the 500 best universities in the world (Hebrew University at 140, Tel Aviv University at 209, the Technion at 220, Ben Gurion University of the Negev at 377, while Weizmann Institute of Science is not ranked, it is an internationally renowned research institution).

In the 1990s, various far-reaching changes took place in Israeli society. In the beginning of the 1990s, around one million Eastern European Jews, mainly from the former Soviet Union, started arriving in Israel, seeking new opportunities and options to build a better, more prosperous life for themselves and their children. In response to this large influx of highly educated immigrants (especially in technology, science and related fields) for which job opportunities needed to be provided, Israel's government created an environment that would be conducive of entrepreneurship. It established dozens of incubators, enabling entrepreneurs to start out in a protected environment. At the same time, the government stimulated the establishment of a venture capital industry to encourage financial investments in the budding start-ups. It also set aside a significant budget for the Chief Scientist Office, which in turn allocated (and continues to do so presently) funds to subsidize the development of applications of new technologies. In parallel, throughout the past two decades, Israel has seen hundreds of entrepreneurial firms being listed on the American NASDAQ stock exchange, which specializes in high tech companies, and after China, has the highest number of foreign companies traded on NASDAQ, as well as on other foreign stock exchanges (Almor, 2011; Avnimelech \& Teubal, 2006; Senor \& Singer, 2008).

In addition, education and especially tertiary education underwent a process of expansion and democratization. Until the late 1980s, academic education was considered mostly a prerogative of the "elite." Immigrants, people from the periphery of Israel and minorities were not easily accepted into academia.

\section{A Period of Growth: A Proliferation of Academic Colleges}

At the end of the 1980s, the universities in Israel were not able to absorb all prospective students. Immigrants from the former Soviet Union as well as Israeli-born high school graduates demanded an academic education. As the existing universities did not increase their acceptance rates, many young people sought academic education outside Israel. This change in demand created two types of academic entrepreneurs: those that helped young people to look abroad and those that sought ways to supply the demand for academic education outside the hegemony of the existing universities.

One of the first to change the existing industry structure was the College of Management. This organization was established by a small group of people, who recognized the need for higher education for a broad group of young people, especially in the field of Business Administration, which was not offered as an undergraduate degree by Israel's existing universities. The College of Management was one of the first to break the hegemony on higher education held by the universities and established a new type of academic institution, one that, while overseen by the Council of Higher Education (CHE), is not funded by government (Clark, 2005). Change in policy of the CHE regarding the ability to grant an academic degree outside the existing industry struc- 
ture, created a watershed of new institutions. During the 1990s and the first decade of the $21^{\text {st }}$ century, Israel witnessed the establishment of tens of new "michlalot" (colleges), which were established by academic entrepreneurs who foresaw increasing demand in higher education (Bank \& Almor, 2013).

Indeed, the number of students in academic institutions in Israel grew from about 81,000 in 1990-91 to about 300,000 in 2010-11 (including students at the Open University). Of all Israeli students in higher education, about 46 percent of freshmen study law, business or some other type of social science, compared to the 35 percent average of the OECD countries. In 1980, about 1,500 students were registered for undergraduate degrees in Management and Economics at Israeli universities. In 2010, about 33,000 students in Israel were studying management, approximately 18,600 of whom were studying in undergraduate programs at academic colleges and an additional 4,700 were taking their graduate MBA at these colleges.

Academic education in Israel is overseen by the Council for Higher Education (CHE), a government-led body that recognizes institutions of higher education, oversees the quality of the programs and allows them to grant degrees. It also serves as an accreditation agency (which otherwise do not exist in Israel) and provides government funding for all universities and part of the colleges. By 2013, Israel had 68 academic institutions, divided into nine universities, 20 colleges and 23 teacher colleges funded by the government, and 16 non-funded colleges.

\section{Maturation of the Academic Education Industry: How Business Schools Will Change}

As growth is leveling off and academic institutions find it increasingly difficult to attract enough students in order to continue growing, especially in colleges where studies are not funded by government (i.e., the student pays full rather than partial tuition), business schools are looking for additional sources of income and growth. Like in many other industries that mature, the generic options seem to be: (1) internationalization, (2) a focus on niches that were previously neglected, and/or (3) a re-examination of the value proposition presented by academia in Israel.

\section{Internationalization of Business Studies: Jewish Diaspora Outreach}

Israeli academia has started to look abroad in trying to attract international students (even though a few universities established international business programs already a decade ago, most business studies in Israel are still conducted in Hebrew). The most logical (and probably easiest) place to look is within the Jewish diaspora, mainly from Englishspeaking countries such as the USA, Canada, Australia, and South Africa, but also European countries where the European Jews have excellent English skills (Russia, France, and Germany have the biggest number of Jewish populations in Europe).
The academic colleges bave created social change and enabled bundreds of thousands of young people to receive an academic education, especially those who would not bave been able to do so previously
Many academics have studied diaspora movements (Brubaker, 2005; Shain \& Barth, 2003) and describe a diaspora as a people with a common origin who reside, more or less on a permanent basis, outside the borders of their ethnic or religious homeland, whether that homeland is real or symbolic, independent or under foreign control. As the central part of their identity and their cause, diasporas retain a collective memory and a longing for an ancestral homeland. Although the modern State of Israel is today a full-fledged member of the international community, located in

During the academic year 2010-11, about 250,000 students participated in higher education (excluding the Open University), of which about 183,000 studied for their first degree.

The academic colleges have created social change and enabled hundreds of thousands of young people to receive an academic education, especially those who would not have been able to do so previously. Nevertheless, as birth rates and immigration numbers have started to decline and the number of academic institutions is still increasing, competition between the academic institutions is growing. Therefore, we expect to see a number of changes in the coming years in the academic education industry and in the business schools specifically. the same territories Jews lived thousands of years ago, having a "Jewish state" had been a dream and a hope of Jews for many centuries. Diaspora members identify themselves, or are identified by others - inside and outside their homeland - as part of the homeland's national community, and as such are often called upon to participate, or are entangled, in homeland-related affairs. The Jewish diaspora is in constant touch and identifies strongly with the State of Israel and as such, many Jews spend some time in Israel, either as part of an exchange at school or university; to partake in the Israeli Defense Forces (IDF); or for religious reasons, i.e., it is expected of many young men to spend a year in a religious school or yeshivah before or after a bachelor's degree. Diaspora Jews tend to be Zionist in their beliefs that Israel should exist out of religious, national, 
or simply reasons of existence as a place to turn to in case of need or for emotional reasons. Hence, this market should be very easy to target, as it is from the onset a captive audience.

In 1997, Bar Ilan University was the first institution to have an international MBA taught entirely in English, as it saw a niche market in the American students who would come to Israel temporarily. It targets mainly those who would go to Israel for a year to a religious school or yeshivah to continue their religious education; being the only religious university in Israel, Bar llan University is the most logical choice for these students. Tel Aviv University's Graduate School of Business Administration soon followed and started a joint executive MBA with Northwestern University's Kellogg School of Management also taught entirely in English. However, these programs were established for reasons other than a glut in the market, such as expanding the enrollment of students, or as a "pull" force, a demand from these students who had some free time to fill in.

Among the colleges, which are more susceptible to fluctuations in number of students, the Interdisciplinary Center (IDC) in Herzliya has established the Raphael Recanati International School (RRIS) which allows students from around the world to study for an undergraduate degree in English with a focus on business administration studies. The Business School of the College of Management-Academic Studies is in the process of establishing a joint degree program with one of the larger business schools in the United States. The Technion in Haifa will be offering a one year MBA in English with an emphasis on high tech entrepreneurship. However, so far very few academic institutions in Israel offer extensive international business studies. It can be expected that more colleges and universities will become increasingly internationally focused as growth in student numbers is leveling off.

\section{Focusing on Niches}

The last few years it has become apparent that certain segments of Israel's society participate less in the democratization process of higher education than others. Most salient are the Ultra-Orthodox Jews, who represent between five to ten percent of the total Israeli population, but who are growing at a six percent rate a year and the Israeli Arabs, who are expected to comprise around 25 percent of the population of Israel by 2025 and who acquire academic education at a much lower percentage than the rest of the population, mainly due to cultural and language reasons. Recently, some colleges have started to focus on either of the two segments. The Ono Academic College, for instance, has established a separate campus for Ultra-Orthodox Jews, where studies in business administration and law are offered on a gender segregated basis. Other colleges have either established or are in the process of establishing separate campuses for this segment of the population as well. As a group, many lack matriculation exams and need preparatory training before they can start with their academic studies. Moreover, many refuse to study with secular Jews or people who do not behave according to their codes of conduct, therefore requiring separate campuses.
Other colleges have started to attract the Israeli Arab population. This requires adaptations as many Israeli Arabs live in the North and the South of Israel, far away from most academic institutions. Many of Israel's Arab students are in need of scholarships and housing, something which most colleges offer in a limited form. While males may live away from home, women are frequently not allowed to do so. In addition, Hebrew is for most a second language and English a third, thus, creating difficulties for those who do not speak Hebrew fluently as studies in Israeli academia are conducted in Hebrew. While some colleges conduct their studies in the Arabic language, most do not and thus will have to find other ways to enable and support this segment to acquire academic education.

\section{Re-Examination of the Value Proposition}

In the past, when relatively few people were able to receive an academic education, the correlation between life-long income and higher education was very strong in Israel. However, in the last few years, this correlation is leveling off and many feel that an academic education is similar nowadays to a matriculation exam some twenty years ago. At the same time, many large employers such as banks, insurance companies, and large manufacturers complain that many of the academic graduates are hired without the appropriate set of skills. Thus, it seems that two important stakeholders, the students on one hand and the employers on the other, are disappointed with academia. Apparently, this process is not unique to Israel. A report published recently by the McKinsey Center for Government (Mourshed, Farell and Barton, 2013) shows that while young people today are three times as likely to be out of a job compared to their parents, many employers cannot find people with the right skills for entry level jobs. In the report, which is based on a survey of nine diverse countries, the authors conclude that academia and industry need to cooperate more closely in order to create graduates that have the skills to find professional work. Some business schools, such as the College of Management, have started to change their curriculum and the auxiliary services and have started to cooperate intensively with industry in order to offer opportunities to their students during their studies to prepare themselves better for future professional employment.

\section{Conclusion}

Israel's higher educational system has been in the making since before the State of Israel was born in 1949. In line with the creativity and entrepreneurship that have characterized businesses in Israel, higher education has also flourished with the burgeoning of many colleges. Nonetheless, growth in the academic education industry is leveling off and expectations of higher education seem to be changing. As a result business schools are looking beyond their borders resulting in the gradual offering of degrees in English and new programs in conjunction with universities abroad. In parallel, business schools are also 
targeting segments of the society it had not considered before, such as the Ultra-Orthodox and the Arab populations. However, most exciting in our view is the change that will take place in the value-proposition offered by business schools in Israel, as important stakeholders are starting to demand studies that offer a well-defined toolkit and skills needed to succeed in the workplace of the $21^{\text {st }}$ century.

\section{References}

Almor, T. 2011. Dancing as fast as they can: Israeli high tech firms and the great recession of 2008. Thunderbird International Business Review, 53(2): 195-208.

Avnimelech, G., \& Teubal, M. 2006. Creating venture capital (VC) industries that co-evolve with high tech clusters: Insights from an extended industry life cycle perspective of the Israeli experience. Research Policy, 35(10): 1477-1498.

Ayalon, H., \& Yogev, A. 2005. Field of study and student's stratification in an expanded system of higher education: The case of Israel. Comparative \& International Higher Education, 21(3): 227-241. http://people.socsci.tau.ac.il/mu/hyalon/files/2010/11/ fieldofstudy2.pdf. Accessed on October 2, 2011.

Bank, D., \& Almor, T. 2013. Business education in a young, entrepreneurial country: The case of Israel. In V. Jones, J. Mclntyre, \& I. Alon (Eds), Innovation in Business Education in Emerging Markets. London: Palgrave.

Breznitz, D. 2002. The military as a public space: The role of the IDF in Israeli software innovation system. MIT Working Paper IPC-02-004. http://web.mit.edu/ipc/publications/pdf/02-004.pdf. Accessed on October 2, 2011.

Brubaker, R. 2005. The "diaspora" diaspora. Ethnic and Racial Studies, 28(1): 1-19.

Clark, T. 2005. Tertiary education in emerging markets: Fertile ground for private investment. Comparative \& International Higher Education, 3(1): 1-7.

Council for Higher Education (CHE) 2011. Website of the Israel Council for Higher Education. http://www.che.org.il/english.aspx. Accessed on October 2, 2011.

Hurn, B. 2009. Will international business always speak English? Industrial and Commercial Training, 41(6): 299-304.

Mourshed, M., Farell, D., Barton, D. 2013. Education to employment: Designing a system that works. McKinsey Center for Government. http://mckinseyonsociety.com/downloads/reports/Education/ Education-to-Employment FINAL.pdf. Accessed on June 12, 2013.

QS World University Rankings. 2012. http://www.topuniversities.com/ university-rankings/world-university-rankings/2012. Accessed on July 11, 2013.
Senor, D., \& Singer, S. 2009. Start-up nation: The story of Israel's economic miracle. New York: Twelve.

Shain, Y., \& Barth, A. 2003. Diasporas and international relations theory. International Organization, 57(3): 449-479.

\section{Endnotes}

1 http://eacea.ec.europa.eu/tempus/participating countries/overview/ israel tempus country fiche final.pdf. Accessed March 31, 2013.

2 The Council for Higher Education (CHE), http://che.org.il/?page id=6802. Table 1. Accessed March 31, 2013.

Tamar Almor has a PhD in international strategy from Tel Aviv University in Israel. At present, she serves as Dean of Students after having held the post of Head of the Department of Strategy and Entrepreneurship at the College of Management, Israel. Her major research interests focus on strategies developed by international new ventures and on international entrepreneurship, and she has published widely in these areas. Currently she serves on a number of editorial boards.

Diana Bank has a PhD in international business and marketing from Bar Ilan University in Israel, and is currently coordinator of masters programs at Universidad de las Américas Puebla (UDLAP), School of Business and Economics, in Puebla, Mexico. Her research interests focus on international business and marketing in emerging markets and she has (co-) authored several articles in this area. 